\title{
UN CAZ RAR DE SINDROM HUNTER - PREZENTARE DE CAZ
}

\author{
Lorena Elena Meliț, Oana Mărginean, Duicu Carmen, Cristina Câmpean, \\ Maria Oana Mărginean \\ Universitatea de Medicină şi Farmacie, Târgu-Mureş
}

\begin{abstract}
REZUMAT
Mucopolizaharidozele (MPZ) sunt un grup de boli genetice rare din marea familie de boli lizozomale. Tulburările (MPZ) sunt cauzate de o deficiență în activitatea unei enzime lizozomale specifice necesare pentru degradarea glicozaminoglicanilor (GAG). MPZ tip II, numită şi sindromul Hunter, constă dintr-un deficit al unei enzime, iduronat-2-sulfataza.

Vă prezentăm un caz rar de sindrom Hunter cu prezentare atipică. Este vorba despre un băiat de 2,7 ani, care s-a prezentat la Clinica Pediatrie I cu simptome de infecție a tractului respirator, cu antecedente de multiple infecții ale otice şi respiratorii. Examenul clinic e evidențiat: statură mare, moderat supraponderal, dismorfism facial (caracteristici faciale grosiere, frunte proeminentă, nas lărgit şi deprimat), degete mici butucănoase, cu flexie a articulațiilor interfalangiene distale, rigiditate articulară, abdomen proeminent cu hernie ombilicală, hepatomegalie şi splenomegalie, precum şi uşor retard mental. Aspectul clinic a fost sugestiv pentru MPZ tip I, II sau VII. Dozarea enzimelor cu rol în metabolismul mucopolizaharidelor lizozomale a relevat un nivel scăzut al iduronat-2-sulfatazei, modificari caracteristice pentru MPZ tip II. Diagnosticul enzimatic a fost confirmat prin analiza ADN-ului molecular care a arătat o mutație a genei hemizigote iduronate-2-sulfatazei la nivelul intronului 3 (c.419-2A>G). S-a instituit terapia de substituție enzimatică genetic recombinată de iduronat-2-sulfatază (Elaprase $\left.{ }^{\circledR}\right)$.

Evoluția cazului, după aproape doi ani de tratament cu Elaprase este favorabilă, fără pierderi ale achizițiilor neurologice.
\end{abstract}

Cuvinte cheie: sindrom Hunter, copil

\section{INTRODUCERE}

Mucopolizaharidoza de tip II sau sindromul Hunter este o boală de stocare lizozomală, care rezultă din deficiența enzimei iduronat-2-sulfatază (IDS). Acest sindrom se transmite genetic, după modelul X-linkat recesiv şi constă într-o mutație homozigotă a genei IDS localizată pe cromozomul Xq28, ducând astfel la compromiterea proteinei sintetizate. Această enzimă fiind responsabilă de degradarea heparan şi dermatan sulfatului, absența sa va duce în cazul pacienților afectați la acumularea acestora în diferite țesuturi, determinând astfel şi trăsăturile clinice ale acestei boli $(1,2)$. Tabloul clinic al acestui sindrom include semne şi simptome cardiovasculare, precum afectarea miocardului şi îngroşare valvulară; afectare neuropsihică: tulburări de comportament, mielopatie cervicală, hidrocefalie, retard mintal, regresia achizițiilor, convulsii şi dificultăți de deglutiție; semne şi simptome digestive: diaree, hepatosplenomegalie; afectare otică: otite medii recurente, pierderea auzului; oculară, şi anume distrofie retiniană; semne şi simptome musculo-scheletale: instabilitate atlanto-axială, sindrom de tunel carpian, dismorfism facial, displazie degenerativă de şold, disostoză multiplex, hernii, contracturi articulare, cifoză şi macrocefalie; şi de asemenea, simptome respiratorii: apnee obstructivă de somn, pneumopatie restrictivă, obstrucția căilor aeriene superioare (3-7). Deşi diagnosticul acestei boli este predominant unul clinic, confimarea lui presupune, de asemenea, mai multe investigații paraclinice (analize de sânge, radiografii, CT, IRM, DEXA, EKG, ecocardiografie, consult neurologic, consult ORL, consult oftalmologic), şi nu în ultimul rând, analiza moleculară a genei IDS, cu importanţă majoră. Tratamentul specific al mucopolizaharidozei de tip II este doar unul substitutiv, 
fără a fi curativ, şi constă în administrarea enzimei iduronat-2-sulfatază.

Prin prezentarea acestui caz, dorim să subliniem trăsăturile clinice atipice ale acestui pacient, cu retard mental uşor şi fără afectare corneană, respectiv problemele de diagnostic şi tratament pe care le ridică acest caz.

\section{PREZENTARE DE CAZ}

Un copil de 2 ani şi 7 luni s-a prezentat la Clinica Pediatrie din Târgu-Mureş, cu multiple infecții acute de căi aeriene superioare şi otite frecvente în antecedente.

Elementele patologice întâlnite pe parcursul examenului obiectiv au fost: statură înaltă (SDS + $3,46)$, supraponderalitate moderată $(+25,97 \%)$, gât scurt, dismorfism facial, frunte proeminentă, piramida nazală turtită, degete mici, groase, cu flexia articulațiilor interfalangiene distale, redoare articulară, abdomen peste planul xifo-pubian, cu hernie ombilicală, hepato-splenomegalie, retard mintal uşor.
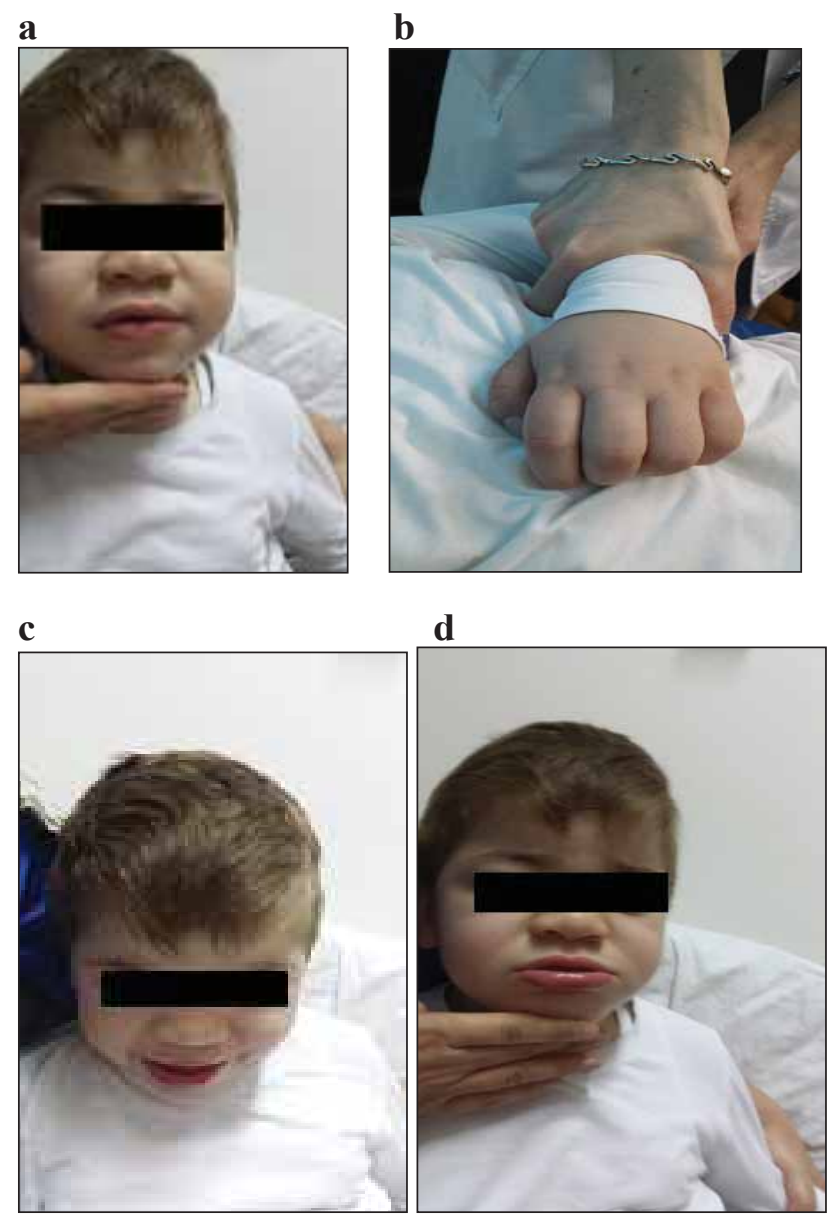

FIGURA 1. $\boldsymbol{a}, \boldsymbol{b}, \boldsymbol{c}, \boldsymbol{d}$. Trăsături fizice caracteristice pentru sindromul Hunter la cazul prezentat
Tabloul clinic al acestui pacient a fost sugestiv pentru mucopolizaharidoză tip I, II sau VII, motiv pentru care au fost efectuate investigații paraclinice pentru elucidarea diagnosticului. Astfel dozajul enzimatic a constat în: $\mathrm{Cl}$. Mainz iduronat sulfataza plasmatică cu o valoare de $6,7986 \mathrm{nM} / \mathrm{ml} / 24 \mathrm{~h}$ (valori de referinţă: 300-800 nM/ml/24h) şi Cl. Rostock iduronat sulfataza plasmatică cu valoare de 1,3 $\mu \mathrm{mol} / \mathrm{l} / \mathrm{h}$ (valori de referință $\geq 2$ ). Analiza moleculară a genei iduronat sulfatază a arătat o mutaţie homozigotă la nivelul intronului 3 (c.419-2 $>$ G). Astfel diagnosticul de mucopolizaharidoză tip II a fost confirmat. Singurul element patologic evidențiat de analizele biochimice şi hematologice de laborator a fost o valoare a imunoglobulinei A de $0 \mathrm{mg} / \mathrm{dl}$. Au fost efectuate, de asemenea, multiple radiografii, şi anume: radiografia mâinii şi a articulației a arătat o vârstă osoasă adecvată pentru 2 ani şi metafize fațetate; radiografia toracică a fost fără modificări pleuro-pulmonare, fără modificări patologice ale cordului, cu arcuri costale mai subțiri la nivelul articulațiilor costo-vertebrale; radiografia coloanei vertebrale a subliniat o tendință spre lordoză, corpi vertebrali lombari cu aspect anterior de cioc; radiografia pelvisului cu următoarele aspecte patologice: pelvis în formă de „cupă“, cu oasele iliace mai dezvoltate decât cele ischio-pubiene, sprânceană cotiloidă orizontală, deformată, cu tendință de răsucire coxo-femurală bilaterală, mai evidentă pe stânga, coxa valga bilateral; iar radiografia antebrațului şi a mâinii a arătat oasele antebrațului cu diafize mai scurte, oasele carpiene cu diafiză angulară, falangele distale în flexie. Astfel, toate aceste elemente radiologice au fost sugestive pentru mucopolizaharidoză tip II. Examinările ultrasonografice, şi anume ecocardiografia şi ecografia abdominală au evidențiat insuficiență aortică grad I, insuficiență mitrală grad I, hipetrofie ventriculară uşoară şi uşoară hepato-splenomegalie. Consultul oftalmologic cu fund de ochi a pus în evidență o papilă contractată, cu excoriație centrală mică a ochiului drept, vase de calibru normal, macula liberă, fără reflex, retină subțire cu vizibilitatea rețelei coroidiene. A fost efectuat de asemenea un consult ORL, care însă a fost fără elemente patologice. Medicul specialist neurolog psihiatru pediatru a stabilit diagnosticul de retard mental uşor.

Diagnosticul nostru de mucopolizaharidoză tip II a fost susţinut pe baza tabloului clinic, a investigațiilor paraclinice şi confirmat de testul genetic.

Odată cu stabilirea diagnosticului s-a iniţiat tratamentul cu substitutiv enzimatic cu Elaprase (forma purificată a enzimei iduronat-2-sulfatază) cu o doză de $0,5 \mathrm{mg} / / \mathrm{kg} /$ doză/săptămână, care se 


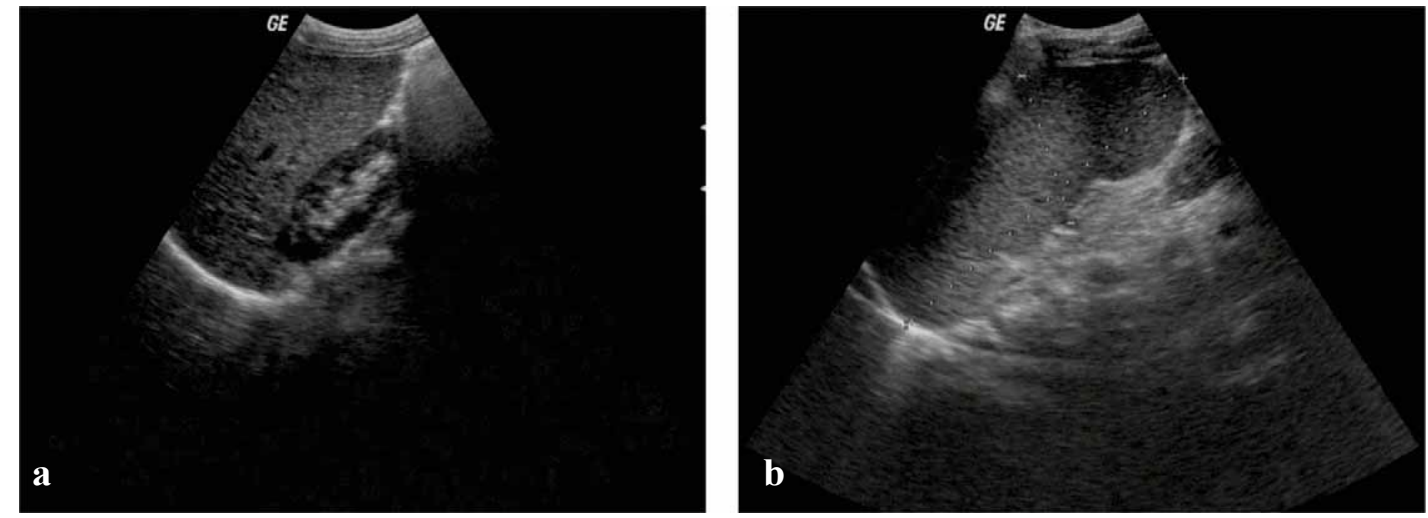

FIGURA 2. a, b. Hepatomegalie şi splenomegalie evidențiate ecografic

administrează săptămânal în Clinica Pediatrie I a Spitalului Clinic de Urgență Târgu-Mureş. Evoluția acestui caz este staționară, însă cu toate acestea prognosticul cazului este nefavorabil deoarece această boală este fără tratament curativ, iar tratamentul substitutiv s-a început tardiv, după ce a s-a instalat retardul neuro-psihic şi după apariția tulburărilor comportamentale.

\section{DISCUȚII}

Mucopolizaharidozele reprezintă un grup de boli genetice rare, care aparțin marii familii a bolilor de stocare lizozomală. Au fost descrise 11 tipuri de mucopolizaharidoze, fiecare din ele constând într-o deficiență a unei enzime specifice de degradare a glicozaminoglicanilor, numiți, de asemenea, mucopolizaharide, ducând astfel la acumularea acestora în țesuturi, şi prin urmare la moarte celulară progresivă şi permanentă, reducând durata vieții $(8,9)$. Mucopolizaharidoza de tip II este numită şi sindrom Hunter după numele medicului canadian Charles Hunter, care în anul 1917, a descris o boală rară întâlnită la doi frați $(3,4)$. Acest sindrom este este unul din cele mai frecvente mucopolizaharidoze, cu o prevalență de 1 la 170.000 de nou-născuți, de sex masculin, pacientul prezentat în cazul nostru fiind tot de sex masculin. În România există 8 cazuri diagnosticate de sindrom Hunter, cel prezentat de noi fiind al şaptelea. Există două forme de mucopolizaharidoză de tip II, una uşoară şi una severă, clasificate în funcție de afectarea sistemului nervos central (7). Astfel, în forma severă, moartea survine de obicei în prima sau a doua decadă de vârstă, iar principalele cauze sunt reprezentate de obstrucția căilor aeriene superioare sau insuficiența cardiacă (6), de aceea recunoaşterea promptă a compromiterii căilor aeriene la pacienții cu sindrom Hunter este foarte importantă şi poate ghida tratamentul (10). În ceea ce priveşte afectarea cardiacă, absența suflurilor precordiale nu exclude cardio- patia, astfel ecocardiografia si electrocardiografia sunt metodele cheie în diagnosticarea acesteia (11). În cazul formelor uşoare, pacienții nu prezintă de obicei afectarea sistemului nervos central, sau dacă prezintă, aceasta este minoră, însă manifestările somatice devin foarte severe până în perioade de adult, ducând la probleme psihologice sau adaptare dificilă în societate (12). Conform tabloului clinic, pacientul nostru a fost încadrat în forma uşoară a sindromului Hunter, dar cu un prognostic nu foarte bun deoarece tratamentul substitutiv s-a început tardiv, după ce a s-a instituit retardul neuro-psihic.

Terapia de substituţie enzimatică cu iduronat-2sulfataza umană recombinantă ar duce la reducerea volumului splinei şi ficatului (13) precum şi la ameliorarea funcţiei respiratorii şi a celei motorii $(14,15)$. Deşi tratamentul substitutiv enzimatic este unul specific, trebuie efectuat şi un tratament suportiv în cazul acestor pacienți deoarece complicațiile acestei patologii sunt vaste şi diverse.

\section{CONCLUZII}

Mucopolizaharidozele sunt boli multisistemice, pentru diagnosticul şi managementul cărora este, fiind necesară o echipă multidisciplinară, şi anume pediatru sau internist, radiolog, genetician, radio$\log$, specialist ORL, oftalmolog, neurolog, şi în anumite cazuri extreme chiar chirurg si specialist de terapie intensivă. Diagnosticul precoce şi respectiv tratamentul substitutiv instituit cât mai repede posibil, sunt recomandate pentru a preveni evoluția bolii şi apariția complicațiilor. $\mathrm{Cu}$ toate că sindromul Hunter, ca şi toate mucopolizaharidozele, nu beneficiază în prezent de un tratament curativ, îmbunătățirea calității vieții acestor pacienți trebuie să se numere printre principalele obiective ale managementului acestei boli genetice rare.

Notă: A fost obținut consimțământul informat al părinților pentru publicarea cazului. 